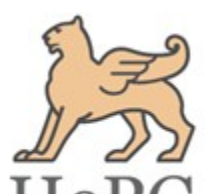
$\mathrm{HePG}$

ISSN: 2348-1900

\title{
Distribution of alkaloids in woody plants
}

\author{
Isabel Desgagné-Penix ${ }^{1,2}$ \\ ${ }^{1}$ Department of Chemistry, Biochemistry and Physics, University of Québec at Trois-Rivières, QC, Canada \\ ${ }^{2}$ Groupe de recherche en biologie végétale, Université du Québec à Trois-Rivières, QC, Canada
}

Article history

Received: 18 July 2017

Accepted: 29 August 2017

Published: 05 September 2017

(C) Desgagné-Penix (2017)

Editor

K K Sabu

Publisher

Horizon e-Publishing Group

Correspondence

Desgagné-Penix I

$\square$ Isabel.Desgagne-Penix@uqtr.ca

\begin{abstract}
Alkaloids are nitrogen-containing compounds found in plants. Most are highly valued for their role in wide array of ailments such as anti-malarial, anti-cancerous, analgesics, and many more. In lights of tremendous interest in recent years on the chemistry and pharmacological properties of alkaloids, comprehensive data have been collected. Forest industries have recently started to develop sustainable ways to increase the value of its residues including the extraction and commercialization of high-valued plant natural compounds such as alkaloids. This review presents the distribution of alkaloids among woody plants (trees and shrubs).
\end{abstract}

\section{Keywords}

Alkaloid; plant secondary metabolism; woody plant; natural products; trees; shrubs; specialized metabolites

\section{Abbreviations}

PNC, plant natural compounds; DMT, N, N-dimethyltryptamine

\section{Citation}

Desgagné-Penix I. Distribution of alkaloids in woody plants. Plant Science Today 2017;4(3):137-142. doi: 10.14719/pst.2017.4.3.320

\section{Introduction}

Morphine, cocaine, quinine, nicotine, caffeine and strychnine are all high-value plant natural compounds (PNC) derived from the specialized (aka secondary) metabolism. These alkaloids are known for their biological activity including analgesic, antimicrobial, stimulant, anti-cancer and even poison depending of the dose used. In 1819, W. Meissner uses the term alkaloid (alkaline compound) to identify plant substances of basic character containing one nitrogen atom (1). To date, more than 21,000 alkaloids have been reported and are classified according to several criteria including their chemical structures, their biosynthetic origins and their biological and ecological activities (2). Most alkaloids characterized to date originate from herbaceous plants and information on alkaloids from woody trees or shrubs are scarce.

Alkaloids are nitrogenous heterocyclic organic molecules derived from amino acids and are mainly found in plants and fungi (3). Although alkaloids are often present in small quantities in plants, they possess potent biological activities at low 
doses. It is proposed that the physiological role of alkaloids is involved in the defense against pathogens and herbivores. Several biological properties of alkaloids including antimicrobial, cytotoxic, analgesic and poison activity seem to support this role. Once purified, alkaloids often have acute toxicity but at low doses, they can serve as medicines. To date, many alkaloids and alkaloid-producing plants are used for the treatment of various ailments. Plant specialized metabolites such as alkaloids have limited distribution compared to primary metabolites because all secondary biogenetic pathways are not operational in all species or tissues and can terminate at different stages. These metabolites can be characteristic of a family, a genus, species, or even cultivars of the same species. They form a basis of chemo-taxonomy because they reflect in part the enzyme systems that produced them, so the genetic makeup of a tree. The alkaloid profile of a plant, or a plant extract, is often presented as a complex mixture which contains some major alkaloids and few minor ones (present at lower concentrations). For example, the alkaloid profiles of opium poppy extracts differ among various cultivars (4).

\section{Woody plants}

Woody plants such as trees and shrubs provide numerous environmental, social and economic benefits for people. In many countries, the forest industry is of major ecological, economic and social importance. As a response to criticism of some forestry practices, sustainable forestry was developed and has become commonplace in many areas. Thus, forest industry continuously develops strategies for better exploitation of the forest resources and new sectors in a sustainable manner. One such sector includes the extraction of high-valued PNC from forest residues. The emergence of this industry is based on three elements: 1) the need for new bioactive natural compounds for the nutraceutical, cosmetic, pharmaceutical and food industry, 2) the search for added alternatives for residues in terms of energy and raw materials, and 3) a way of recovering forest biomass to gain greater profitability. Some of forest PNC identified possess several physicochemical, biological and therapeutic activities. For example, residual barks are rich in polyphenols which have recognized properties as antioxidants, anticancer agents, antibiotics, or anti-inflammatories. Thus, the extraction of forest residues such as bark, provides a wide range of products and according to their properties, multiple applications can be envisaged. For example, terpene monomers (pinene, limonene) can enter the formulation of perfumes, phenolic compounds (tannins) are good replacements for phenol in resins for wood-based materials, and simple phenols (stilbenes, lignans, flavonoids) can be included in the formulation of products in nutrition of animal or human health. To date, few comprehensive phytochemical studies have focused on residual tissues of woody plant species and even less reported the presence of alkaloids. Consequently, in the world of commercial wood extracts, alkaloids are often forgotten due to lack of information on the presence of these compounds in the studied species and / or their low accumulation in trees. Therefore, the current review reports the alkaloids detected in woody plants.

\section{Alkaloids in woody plants}

In contrast to the extensive literature on PNC of the terpenoid and phenolic groups in woody plants (trees and shrubs), information on the alkaloid group is rare, sparse and limited. Table 1 presents a summary of the literature on the alkaloids present in woody plants. Alkaloids are reported and classified according to their chemical structure.

One important alkaloid from trees is taxol (paclitaxel ${ }^{\circledR}$ ), a successful anti-cancer agent from Taxus brevifolia (5). It was first isolated and characterized as part of the National Cancer Institute screening program (6). Since, several other compounds including tree alkaloids, have been identified and characterized as anti-cancer agents including camptothecine, rohitukine, harringtonine, acronycine and ellipticine (Table 1) (5).

Purine alkaloids, also called xanthines, includes the well-known PNCs caffeine, theobromine and theophylline (7). The coffee plant (Coffea arabica), a shrub of the Rubiaceae family which is grown for its coffee beans, produced caffeine and other purine alkaloids (Table 1) (7). The cacao tree (Theobroma cacao) is a small tree in the Sterculiaceae family producing theobromine in its beans from which cocoa is produced (8). The kola tree (Cola acuminata), from the same family as cocoa, produces kola nut, a fruit containing purine alkaloids such as caffeine, kolatine and kolateine (7, 9). Purine alkaloids also exist in several non-woody plants such as guarana, mate and tea. Purine alkaloid allows the plant to protect itself from attack by insects and other herbivores.

In addition to purine alkaloids, the Rubiaceae family includes the quinine tree (Cinchona pubescens) sought for its bark with antimalarial activity. It produces quinoline alkaloids such as quinine, quinidine, cinchonine (3) Lemon aspen (Acronychia acidula) and several other species of Acronychia produce quinoline (acridone) alkaloids such acronycine, melicopine, melicopidine and acronycidine (Table 1) (10). From the same plant family, several species of Sarcomelicope also produce acronycine and other quinoline alkaloids (11).

Coca bush (Erythroxylum Coca) is a tropical shrub from South America producing the tropane 
Table 1: List of alkaloids reported in several families of woody plant such as trees and shrubs.

\begin{tabular}{|c|c|c|c|c|}
\hline Alkaloid group & Plant family & Example of species & Example of alkaloid & Reference \\
\hline Taxane & Taxaceae & Taxus brevifolia & taxol (paclitaxel) & $(6,44)$ \\
\hline Chromone & Meliaceae & Amoora rohituka & rohitukine & $(45)$ \\
\hline Cephalotaxine & Cephalotaxaceae & Cephalotaxus harringtonia & harringtonine & $(46)$ \\
\hline Purine & Rubiaceae & Coffea arabica & caffeine & (7) \\
\hline Purine & Sterculiaceae & Theobroma cacao & theobromine & (8) \\
\hline Purine & Sterculiaceae & Cola acuminata & kolatine & (9) \\
\hline Quinoline & Rubiaceae & Cinchona pubescens & quinine & (3) \\
\hline Quinoline & Nyssaceae & Camptotheca acuminata & camptothecine & $(47)$ \\
\hline Quinoline & Rutaceae & Acronychia acidula & acronycine & $(10)$ \\
\hline Quinoline & Rutaceae & $\begin{array}{l}\text { Sarcomelicope } \\
\text { glauca }\end{array}$ & acronycine & (11) \\
\hline Tropane & Erythroxylaceae & Erythroxylum coca & cocaine & $(12)$ \\
\hline Tropane & Moraceae & Morus alba & 1-deoxynojirimycin & (13) \\
\hline Nortropane & Erythroxylaceae & Erythroxylum coca & calystegine & $(48)$ \\
\hline Phenethylamine & Fabaceae & Acacia rigidula & dimethyltryptamine & $(15,17)$ \\
\hline $\begin{array}{l}\text { Phenethylamine } \\
\text { Indole }\end{array}$ & Fabaceae & Anadenanthera peregrina & $\begin{array}{l}\text { bufotenine } \\
\text { harmine }\end{array}$ & (16) \\
\hline Indole & Aceraceae & Acer saccharinum & harmine & (18) \\
\hline Indole & Simaroubaceae & Simarouba glauca & cathin-6-one & (19) \\
\hline Indole & Rubiaceae & Pausinystalia yohimbe & yohimbine & $(3,23,24)$ \\
\hline Indole & Rubiaceae & Mitragyna speciosa & mitragynine & $(21,22)$ \\
\hline Indole & Loganiaceae & Strychnos nux-vomica & strychnine & $(3,25)$ \\
\hline Indole & Loganiaceae & Strychnos usambarensis, & usambarensine & $(49)$ \\
\hline Indole & Apocynaceae & Ochrosia elliptica & ellipticine & $(50)$ \\
\hline Pyridine & Lythraceae & Punica granatum & pyridine & (26) \\
\hline Piperidine & Piperaceae & Piper nigrum & piperine & $(28)$ \\
\hline Piperidine & Pinaceae & Pinus pondorosa & euphococcine & $(29,30,32)$ \\
\hline Piperidine & Pinaceae & Picea abies & cis-pinidine & $(29,31)$ \\
\hline Isoquinoline & Lauraceae & Sassafras albidum & boldine & $(33,35)$ \\
\hline Isoquinoline & Lauraceae & Cinnamomum mollissimum & cinnamolaurine & $(33,36)$ \\
\hline Isoquinoline & Magnoliaceae & Liriodendron tulipa & $N$-methylcrotsparine & $(37-39)$ \\
\hline Isoquinoline & Magnoliaceae & Elmerrillia papuana & elmerrillicine & $(40)$ \\
\hline
\end{tabular}

alkaloid cocaine (Table 1) (12). Mulberry trees (Morus alba) also produce tropane alkaloids such as 1-deoxynojirimycin, also named sugar-mimicalkaloids because of their structure and their activity against diabetes and obesity $(13,14)$. Acacia trees from the Fabaceae family are known to produce phenethylamine alkaloids such as $N, N$ dimethyltryptamine (DMT) and other catecholamines (Table 1) (15). DMT is a controlled substance with effects on the nervous system drugs such as 3,4-methyenedioxymethamphetamine (MDMA) and ecstasy. In addition to synthesizing phenethylamine alkaloids (DMT, bufotenine), the yopo (Anadenanthera peregrina), a South American tree that looks like
Acacia, produces indole alkaloids called bcarbolines such as harmine, harmaline, elaeagnine and tryptoline (Table 1) $(16,17)$. It has been reported that other woody species also accumulate b-carboline alkaloids including the maple tree (Acer saccharinum) which produces harmine and elaeagnine and the simarouba tree (Simarouba glauca) which synthesizes cathin-6-one and others b-carbolines derivatives (Table 1) (18-20). Alkaloids in the Rutaceae family including canthin-6-one, isolated from bark and leaves of Zanthoxylum has cytotoxic and anti-tumor properties (20). Kratom (Mitragyna speciosa), a tree found in South East Asia and Africa and used for its wood, belong to the Rubiaceae family same 
as Cinchona and coffee trees, but produces indole alkaloids such as mitragynine and paynantheine (Table 1) $(21,22)$. Other indole alkaloids produced by tropical trees include yohimbine from Pausinystalia yohimbe and strychnine from Strychnos nux-vomica $(3,23-25)$.

The pomegranate tree (Punica granatum) produces pyridine alkaloids (26). Alkaloids were reported to accumulate in white birch but the authors did not specify which ones (27).

Black pepper (Piper nigrum) is a woody vine from the Piperaceae family producing berries that give a sought-pepper spice. Piperine with other piperidine alkaloids are responsible for the sensation of heat when eating black pepper. (28) It is interesting to note that in the Pinaceae family (Pine trees), including the genus Pinus and Picea, also accumulates piperidine alkaloids such as euphococcinine, 2-methyl-6-propyl-1,6-piperidine and cis-pinidine (Table 1) (29-32).

Finally, the Lauraceae family includes several species able to produce isoquinoline alkaloids $(33,34)$. The most frequently detected alkaloids in Lauraceae barks include reticuline, boldine, aporphine, corydine, cinnamolaurine, laurotetatnine and laurolitsine $(33,35,36)$. These species include the Iroquois bay (Sassafras albidum) used in medicine for its antiseptic properties and as a spice in Cajun cooking and the cinnamon tree (Cinnamomum mollissimum) providing cinnamon and lumber. Some Magnoliaceae also produces isoquinoline alkaloids including yellow poplar (Liriodendron tulipa) accumulating $N$-methylcrotsparine and Elmerrillia papuana producing elmerrillicine (3740).

\section{Conclusions}

Finding natural, new, safe and economical PNC, especially from abundant and low-value raw materials is a real challenge, especially in an effort to develop "green" product in a sustainable manner (41). Some industries (pharmaceutics, cosmetics, food additives and nutraceuticals) have increased their efforts to obtain and use commercially bioactive PNCs from diverse plant residues. Forest biomass (mainly trees and shrubs) often contains bioactive PNCs of commercial values. These residues of industrial wood transformation are available in huge quantities, representing an abundant and inexpensive source of bioactive PNC $(42,43)$. Alkaloids, due to the wide range of biological effects, may represent an interesting avenue for the forest industry to add value to their products and processes.

\section{Author Contribution Statement}

IDP designed, structured and wrote the manuscript.

\section{Conflict of Interest}

The author declares that she has no conflict of interest.

\section{Acknowledgments}

This work was supported by grants from the Natural Sciences and Engineering Research Council of Canada.

\section{References}

1. Hesse M. Alkaloids: Nature's Curse Or Blessing?: Verlag Helvetica Chimica Acta; 2002.

2. Wink M. Biochemistry of plant secondary metabolism. Annual plant reviews. 2010;40.

3. Dewick PM. Medicinal natural products: a biosynthetic approach. 3rd ed: John Wiley and Sons Ltd; $2009 . \quad 539 \quad$ p. https://doi.org/10.1002/9780470742761

4. Desgagne-Penix I, Farrow SC, Cram D, Nowak J, Facchini PJ. Integration of deep transcript and targeted metabolite profiles for eight cultivars of opium poppy. Plant Mol Biol. 2012;79(3):295-313. https://doi.org/10.1007/s11103-012-9913-2

5. Isah T. Anticancer Alkaloids from Trees: Development into Drugs. Pharmacogn Rev. 2016;10(20):90-9. https://doi.org/10.4103/09737847.194047

6. Wani MC, Taylor HL, Wall ME, Coggon P, McPhail AT. Plant antitumor agents. VI. The isolation and structure of taxol, a novel antileukemic and antitumor agent from Taxus brevifolia. Journal of the American Chemical Society. 1971;93(9):2325-7. https://doi.org/10.1021/ja00738a045

7. Ashihara H, Sano H, Crozier A. Caffeine and related purine alkaloids: Biosynthesis, catabolism, function and genetic engineering. Phytochemistry. 2008;69(4):841-56.

https://doi.org/10.1016/j.phytochem.2007.10.029

8. Koyama Y, Tomoda Y, Kato M, Ashihara H. Metabolism of purine bases, nucleosides and alkaloids in theobromine-forming Theobroma cacao leaves. Plant Physiology and Biochemistry. 2003;41(11-12):977-84.

https://doi.org/10.1016/j.plaphy.2003.07.002

9. Niemenak N, Onomo PE, Fotso, Lieberei R, Ndoumou DO. Purine alkaloids and phenolic compounds in three Cola species and Garcinia kola grown in Cameroon. South African Journal of Botany. 2008;74(4):629-38. https://doi.org/10.1016/j.sajb.2008.03.003

10. Epifano F, Fiorito S, Genovese S. Phytochemistry and pharmacognosy of the genus Acronychia. Phytochemistry. 2013;95:12-8. https://doi.org/10.1016/j.phytochem.2013.07.013

11. Tillequin F. Alkaloids in the genus Sarcomelicope. Recent Research Develop Phytochemistry. 1997;1:675-87.

12. Moore JM, Moore JF, Fodor G, Jones AB. Detection and Characterization of Cocaine and Related Tropane Alkaloids in Coca Leaf, Cocaine, and Biological Specimens. Forensic science review. 1995;7(2):77-101.

13. Asano N, Yamashita T, Yasuda K, Ikeda K, Kizu H, Kameda Y, et al. Polyhydroxylated alkaloids 
isolated from mulberry trees (Morusalba L.) and silkworms (Bombyx mori L.). J Agric Food Chem. 2001;49(9):4208-13. https://doi.org/10.1021/jf010567e

14. Hirayama C, Konno K, Wasano N, Nakamura M. Differential effects of sugar-mimic alkaloids in mulberry latex on sugar metabolism and disaccharidases of Eri and domesticated silkworms: Enzymatic adaptation of Bombyx mori to mulberry defense. Insect Biochemistry and Molecular Biology. 2007;37(12):1348-58. https://doi.org/10.1016/j.ibmb.2007.09.001

15. Wahba Khalil SK, Elkheir YM. Dimethyltryptamine from the leaves of certain Acacia species of northern Sudan. Lloydia. 1975;38(2):176-7.

16. Duke D. Phytochemical and Ethnobotanical Databases. [Online Database] 2015

17. Clement BA, Goff CM, Forbes TDA. Toxic amines and alkaloids from Acacia rigidula. Phytochemistry. 1998;49(5):1377-80. https://doi.org/10.1016/S0031-9422(97)01022-4

18. Patcher IJ, Zacharias DE, Ribeiroi O. Indole Alkaloids of Acer saccharinum (the Silver Maple), Dictyoloma incanescens, Piptadenia colubrina, and Mimosa hostilis. Journal of Organic Chemistry. 1959;24(9):1285-7. https://doi.org/10.1021/jo01091a032

19. Rivero-Cruz JF, Lezutekong R, Lobo-Echeverri T, Ito A, Mi Q, Chai HB, et al. Cytotoxic constituents of the twigs of Simarouba glauca collected from a plot in Southern Florida. Phytotherapy research : PTR. 2005;19(2):136-40. https://doi.org/10.1002/ptr.1642

20. Cebrian-Torrejon G, Kahn SA, Ferreira ME, Thirant C, Rojas de Arias A, Figadere B, et al. Alkaloids from Rutaceae: activities of canthin-6-one alkaloids and synthetic analogues on glioblastoma stems cells. MedChemComm. https://doi.org/10.1039/c2md20047c 2012;3(7):771-4.

21. Takayama H. Chemistry and pharmacology of analgesic indole alkaloids from the rubiaceous plant, Mitragyna speciosa. Chemical \& pharmaceutical bulletin. 2004;52(8):916-28. https://doi.org/10.1248/cpb.52.916

22. Avula B, Sagi S, Wang YH, Wang M, Ali Z, Smillie TJ, et al. Identification and Characterization of Indole and Oxindole Alkaloids from Leaves of Mitragyna speciosa Korth Using Liquid ChromatographyAccurate QToF Mass Spectrometry. Journal of AOAC International. 2015;98(1):13-21. https://doi.org/10.5740/jaoacint.14-110

23. Zanolari B, Ndjoko $\mathrm{K}$, Ioset JR, Marston $\mathrm{A}$, Hostettmann K. Qualitative and quantitative determination of yohimbine in authentic yohimbe bark and in commercial aphrodisiacs by HPLC-UVAPI/ MS methods. Phytochemical analysis : PCA. 2003;14(4):193-201. https://doi.org/10.1002/pca.699

24. Authority EFS. Scientific Opinion on the evaluation of the safety in use of Yohimbe (Pausinystalia yohimbe (K. Schum.) Pierre ex Beille). EFSA Journal. 2013;11(7):3302. https://doi.org/10.2903/j.efsa.2013.3302

25. Jonville M-C, Dive G, Angenot L, Bero J, Tits M, Ollivier E, et al. Dimeric bisindole alkaloids from the stem bark of Strychnos nux-vomica L. Phytochemistry. 2013;87:157-63. https://doi.org/10.1016/j.phytochem.2012.11.002
26. Schmidt A, Mordhorst T, Nieger M. Investigation of a betainic alkaloid from Punica granatum. Natural product research. 2005;19(5):541-6. https://doi.org/10.1080/14786410500034949

27. Zyryanova OA, Terazawa M, Koike T, Zyryanov VI. White Birch Trees as Resource Species of Russia: Their Distribution, Ecophysiological Features, Multiple Utilizations. Eurasian Journal of Forest Research. 2010;13(1):25-40.

28. Liu H-L, Luo R, Chen X-Q, Ba Y-Y, Zheng L, Guo W$\mathrm{W}$, et al. Identification and simultaneous quantification of five alkaloids in Piper longum L. by HPLC-ESI-MSn and UFLC-ESI-MS/MS and their application to Piper nigrum L. Food Chemistry. 2015;177:191-6.

https://doi.org/10.1016/j.foodchem.2015.01.033

29. Tawara JN, Blokhin A, Foderaro TA, Stermitz FR, Hope H. Toxic piperidine alkaloids from pine (Pinus) and spruce (Picea) trees. New structures and a biosynthetic hypothesis. The Journal of Organic Chemistry. 1993;58(18):4813-8. https://doi.org/10.1021/jo00070a014

30. Gerson E, Kelsey R. Variation of Piperidine Alkaloids in Ponderosa (Pinus poderosa) and Lodgepole Pine $(P$. contorta) Foliage from Central Oregon. Journal of chemical ecology. 1998;24(5):815-27. https://doi.org/10.1023/A:1022369416745

31. Virjamo V, Julkunen-Tiitto R. Shoot development of Norway spruce (Picea abies) involves changes in piperidine alkaloids and condensed tannins. Trees. 2014;28(2):427-37. https://doi.org/10.1007/s00468013-0960-3

32. Gerson EA, Kelsey RG, St Clair JB. Genetic variation of piperidine alkaloids in Pinus ponderosa: a common garden study. Annals of botany. 2009;103(3):447-57. https://doi.org/10.1093/aob/mcn228

33. Custodio DL, Florencio da Veiga Junior V. Lauraceae alkaloids. RSC Advances. 2014;4(42):21864-90.

https://doi.org/10.1039/C4RA01904K

34. Silva JRdA, CarmoI DFMd, Reis ÉM, Machado GMC, Leon LL, Silva BOd, et al. Chemical and biological evaluation of essential oils with economic value from Lauraceae species. J Braz Chem Soc. 2009;20(6):1071-6. https://doi.org/10.1590/S010350532009000600011

35. Chowdhury BK, Sethi ML, Lloyd HA, Kapadia GJ. Aporphine and Tetrahydrobenzylisoquinoline Alkaloids in Sassafras albidum. Phytochemistry. 1976;15:1803-4. https://doi.org/10.1016/S00319422(00)97502-2

36. Masnon FF, Hassan NP, Ahmad F. Aporphine alkaloids of Cinnamomum mollissimum and their bioactivities. Natural product communications. 2014;9(1):31-2.

37. Rowe J, Conner A. Extractives in eastern hardwoods: a review. Gen Tech Rep. 1979;FPL-18:167.

38. Devappa RK, Rakshit SK, Dekker RFH. Forest biorefinery: Potential of poplar phytochemicals as value-added co-products. Biotechnology Advances. (0).

39. Barbosa P, Gross P, Provan GJ, Pacheco DY, Stermitz FR. Allelochemicals in foliage of unfavored tree hosts of the gypsy moth, Lymantria 
dispar L.: 1. Alkaloids and other components of Liriodendron tulipifera L. (Magnoliaceae), Acer rubrum L. (Aceraceae), and Cornus florida L. (Cornaceae). Journal of Chemical Ecology. 1990;16(5):1719-30.

https://doi.org/10.1007/BF01014103

40. Cleaver L, Nimgirawath S, Ritchie E, Taylor W. The alkaloids of Elmerrillia papuana (Magnoliaceae): Structure and synthesis of elmerrillicine. Australian Journal of Chemistry. 1976;29(9):2003-21. https://doi.org/10.1071/CH9762003

41. Pretzsch H, Grote R, Reineking B, Rotzer T, Seifert S. Models for forest ecosystem management: a European perspective. Annals of botany. 2008;101(8):1065-87. https://doi.org/10.1093/aob/mcm246

42. Garcia-Perez ME, Royer M, Herbette G, Desjardins Y, Pouliot R, Stevanovic T. Picea mariana bark: a new source of trans-resveratrol and other bioactive polyphenols. Food Chem. 2012;135(3):1173-82. https://doi.org/10.1016/j.foodchem.2012.05.050

43. Mulat DG, Latva-Maenpaa H, Koskela H, Saranpaa P, Wahala K. Rapid chemical characterisation of stilbenes in the root bark of Norway spruce by offline HPLC/DAD-NMR. Phytochemical analysis : PCA. 2014;25(6):529-36. https://doi.org/10.1002/pca.2523

44. Roberts MF, Strack D, Wink M. Biosynthesis of Alkaloids and Betalains. Annual Plant Reviews Volume 40: Biochemistry of Plant Secondary Metabolism: Wiley-Blackwell; 2010. p. 20-91. https://doi.org/10.1002/9781444320503.ch2
45. Harmon AD, Weiss U, Silverton JV. The structure of rohitukine, the main alkaloid of Amoora rohituka (syn. Aphanamixis polystachya) (Meliaceae) [leaves and stems]. Tetrahedron. 1979;20:721-4. 4039(01)93556-7

46. Powell RG, Weisleder D, Smith CR, Wolff IA. Structure of cephalotaxine and related alkaloids. Tetrahedron Letters. 1969;10(46):4081-4. https://doi.org/10.1016/S0040-4039(01)88620-2

47. Lopez-Meyer M, Nessler CL, McKnight TD. Sites of accumulation of the antitumor alkaloid camptothecin in Camptotheca acuminata. Planta medica. https://doi.org/10.1055/s-2006-959571

48. Cordell GA. Fifty years of alkaloid biosynthesis in Phytochemistry. Phytochemistry. 2013;91(0):2951. https://doi.org/10.1016/j.phytochem.2012.05.012

49. Saidou Balde el H, Megalizzi V, Cao M, Angenot L, Kiss $\mathrm{R}$, Van Damme $\mathrm{M}$, et al. Isostrychnopentamine, an indolomonoterpenic alkaloid from Strychnos usambarensis, with potential anti-tumor activity against apoptosisresistant cancer cells. Int J Oncol. 2010;36(4):9615.

50. Goodwin S, Smith A, Horning E. Alkaloids of Ochrosia elliptica. Journal of the American Chemical Society. 1959;81:1903-8. https://doi.org/10.1021/ja01517a031 